PAWLOWSKA, J., ZAJĄCZKOWSKI, M., SZCZUCIŃSKI, W., ZABORSKA, A., KUCHARSKA, M., JERNAS, P., FORWICK, M. : The influence of Coriolis force driven water circulation on the palaeoenvironment of Hornsund (S Spitsbergen) over the last century

The influence of the Coriolis force on the Hornsund fjord environment (southern Spitsbergen) was investigated in the marine sedimentary record from the last century. Due to the influence of the rotational effects, Atlantic and Arctic water enters the fjord along the southern shore and exits along the northern shore. Thus, the sedimentary record from the southern part reflects the large-scale hydrologic processes associated with these oceanic water masses, whereas the northern portion is affected by a combination of regional and local waters (including glacial meltwater). To assess the significance of the Coriolis force-driven circulation in this environment over the last century, two short sediment cores were sampled from the southern and northern parts of the fjord. The cores were dated with ${ }^{210} \mathrm{~Pb}$ and ${ }^{137} \mathrm{Cs}$ and analysed for grain size, ice rafted debris, benthic foraminifera and the stable isotopes $\left(\delta^{18} \mathrm{O}\right.$ and $\left.\delta^{13} \mathrm{C}\right)$. The influence of the Coriolis force was most apparent in the benthic foraminiferal record. The foraminiferal assemblage of the southern part of the fjord is characterized by markedly higher species diversity and a high percentage of Atlantic water species compared to the northern part. This pattern likely resulted from the lower level of environmental disturbance and the constant introduction of propagules and juveniles from offshore pools. The northern part of the fjord is characterized by more unstable environmental conditions due to the variable delivery of turbid meltwater, which is reflected in the lowdiversity foraminiferal assemblage dominated by glaciomarine taxa and bottom current indicators. The influence of the Coriolis force on the sedimentary regime is less clear. Since the geometry of many of the European Arctic fjords allows the rotational dynamics of water 
masses, our results may serve as a reference for further studies on the influence of the Coriolis force-driven rotational dynamics on modern and past environments.

Joanna Pawłowska (pawlowska@iopan.pl), Marek Zajączkowski and Matgorzata Kucharska, Marine Ecology Department, Institute of Oceanology, Polish Academy of Sciences, Powstańców Warszawy 55, 81 - 712 Sopot, Poland; Witold Szczuciński, Institute of Geology, Adam Mickiewicz University in Poznań, Maków Polnych 16, 61-606 Poznań, Poland; Agata Zaborska, Marine Chemistry and Biochemistry Department, Institute of Oceanology, Polish Academy of Sciences, Powstańców Warszawy 55, 81 - 712 Sopot, Poland; Patrycja Ewa Jernas, Matthias Forwick, Department of Geoscience, University of Tromsø - The Arctic University of Norway, Postboks 6050 Langnes, N-9037 Tromsø, Norway 
Fjords are unique settings that archive information about terrestrial and marine environmental changes at local and regional scales. The stratigraphic interpretation of fjord sedimentary records can provide insight into past climatic and environmental conditions (e.g. Andrews \& Syvitski 1994) at mid- to high latitudes, e.g. Greenland (Seidenkrantz et al. 2007), Canada (Dallimore et al. 2008), the European Arctic (Jernas et al. 2013), Antarctica (Gilbert et al. 2003), and Chile (Sepúlveda et al. 2009). Due to their high sediment accumulation rates, fjords potentially archive records of environmental changes with high temporal resolution (Gilbert 2000).

The oceanographic conditions in the fjords of western Spitsbergen are strongly related to the inflow of warm and saline Atlantic Water (AW) as well as glacial meltwater (Svendsen et al. 2002; Nilsen et al. 2008; Forwick et al. 2010). The distribution and circulation of water masses in fjords are affected by a variety of factors, including wind, freshwater discharge, tidal pumping and rotational dynamics caused by the Coriolis force (e.g. Skarðhamar \& Svendsen 2010). Among these processes, freshwater discharge and water mass movement caused by tidal pumping are steered by the Coriolis force. The impact of wind is temporary and can be neglected in terms of the long-term sedimentary record. Due to the Coriolis force, shelf water entering the fjords of the northern hemisphere is deflected towards the right-hand shore (Nilsen et al. 2008), affecting the distribution of brackish and saline waters across the fjord (e.g. Svendsen et al. 2002) and the sedimentation patterns (e.g. Gilbert et al. 1998; Howe et al. 2003). The influence of the rotational effects on the water mass distribution depends on the width of the fjord compared to the internal radius of deformation (the socalled internal Rossby radius; Gilbert 1983) as well as on the velocity of the deflected current. The widths of the outer parts of Arctic fjords usually exceed the Rossby radius by 2-3 times, thus allowing for rotation of water masses within the fjords (Cottier et al. 2010). 
Climate-induced changes in water-mass composition and water circulation affect the functional properties of ecosystems and lead to changes of fjords productivity and biodiversity (e.g., Berge et al. 2005; Cottier et al. 2005; Zajączkowski et al. 2010b; Pawłowska et al. 2011). In glaciated fjords, the strong environmental gradients in turbid water input and sedimentation induce large changes in the benthic community composition and its abundance from the inner to outer areas of the fjords (Svendsen et al. 2002; Jernas 2012; Włodarska-Kowalczuk et al. 2013). Benthic foraminiferal abundance and species composition in the Spitsbergen fjords are mainly controlled by glacial meltwater discharge and AW inflow (Hald \& Korsun 1997; Korsun \& Hald 2000; Pogodina 2005) - two factors that are strongly affected by climate change. Benthic foraminiferal census data and stable isotope compositions obtained from foraminiferal tests are valuable data sets in the sedimentary record in fjords. They are commonly applied in Arctic and sub-Arctic regions on centennial to millennial timescales (e.g. Majewski \& Zajączkowski 2007; Skirbekk et al. 2010; Jernas et al. 2013). However, to our knowledge, the direct relationships between foraminiferal distributions in fjords and the Coriolis force have not been studied before.

The aim of this study is to define the influence of the Coriolis force on the benthic foraminiferal fauna assemblages in Hornsund fjord (Spitsbergen) during the 20th century. The study is based on the multi-proxy analysis (including foraminiferal biodiversity, the isotopic composition of foraminiferal tests and sedimentological properties) of two sediment cores retrieved from the northern and southern parts of the fjord. These records reveal environmental variability in Hornsund caused by large-scale oceanographic processes related to variations in the inflow of water from the Atlantic and by changes in the local cryosphere and oceanography. 


\section{Study area}

Hornsund is the southernmost fjord system in western Spitsbergen. It comprises a main basin and multiple side bays, particularly in the inner parts (Fig. 1B). The entire system is $\sim 32 \mathrm{~km}$ long and up to $10 \mathrm{~km}$ wide. Sills at water depths of $\sim 100 \mathrm{~m}$ separate the main fjord from the inner bays. The main fjord basin is $>250 \mathrm{~m}$ deep, and the glacier-proximal basins are $180 \mathrm{~m}$ (Burgerbukta and Samarinvågen), 150 m (Brepollen) and 55 m (Isbjörnhamna) deep.

The water masses in the fjord are influenced by Shelf Transformed Water (STW), which forms over the continental shelf via mixing of the warm and saline Atlantic Water (AW) carried northward by the West Spitsbergen Current and the colder and fresher Arctic Water (ArW) transported by the East Spitsbergen Current (Fig. 1A; Beszczyńska-Möller et al. 1997). Winter Cooled Water (WCW) with temperatures below $-0.5^{\circ} \mathrm{C}$ occupies the innermost near-bottom part of the fjord (Beszczyńska-Möller et al. 1997).

The drainage area of Hornsund is almost $70 \%$ covered by glaciers, which makes it one of the most glaciated areas in Svalbard (Hagen et al. 1993; Błaszczyk et al. 2013). Tidewater glaciers constitute $97 \%$ of the glaciated area. During the last century, glaciers in Hornsund have significantly retreated, and their total area has decreased by approximately $172 \mathrm{~km}^{2}$ (Błaszczyk et al. 2013).

Węsławski et al. (1991) reported a significant contribution of glacier meltwater runoff to Hornsund waters. In addition to meltwater, glaciers supply significant amounts of sediment to the fjord system. The concentration of suspended mineral particles varies during the summer from $35 \mathrm{mg} \mathrm{dm}^{-3}$ in the inner basin to $1.5 \mathrm{mg} \mathrm{dm}^{-3}$ in the central and outer basins (Zajączkowski pers. obs.). Modern sediment accumulation rates in the fjord range from 0.5 $\mathrm{cm} \mathrm{a}^{-1}$ in the central part to $0.7 \mathrm{~cm} \mathrm{a}^{-1}$ at the fjord head (Szczuciński et al. 2006).

The bottom sediments in Hornsund are characterized by the presence of four main lithofacies (Görlich 1986). In glacier-proximal settings sediments are composed of stratified 
sandy mud, with sand and gravel. With increasing distance from the tidewater glacier fronts, organically laminated muds intercalated with coarse-grained layers dominate, and in glacierdistal settings, homogenous, bioturbated mud with coarse-grained intercalations is found. Additionally, sandy gravel is documented in shallow water (Görlich 1986).

There is a distinctive gradient of foraminiferal fauna from the inner to outer parts of Hornsund. The density and species richness of foraminifera decrease in the vicinity of the glaciers (Włodarska-Kowalczuk et al. 2013). According to Hald \& Korsun (1997), the innermost part of Hornsund is dominated by glaciomarine species, mainly Elphidium excavatum and Cassidulina reniforme. Characteristic species of the outer and central fjord are Nonionellina labradorica, Recurvoides turbinatus, Bucella frigida, Adercotryma glomerata and Islandiella norcrossi. Similar observations were made by Pogodina (2005), Zajączkowski et al. (2010a) and Włodarska-Kowalczuk et al. (2013).

\section{Material and methods}

The two 30-cm-long sediment cores NORTH and SOUTH were retrieved with box corers during scientific cruises of the R/V Oceania in 2012 and R/V Helmer Hanssen (formerly R/V Jan Mayen) in 2009, respectively. The NORTH core was retrieved from a depth of $125 \mathrm{~m}$, whereas the SOUTH core was retrieved from $130 \mathrm{~m}$ (Fig. 1B). The cores were stored at $4{ }^{\circ} \mathrm{C}$ and shipped to the Institute of Oceanology PAN for further analysis, where they were subsampled at $1 \mathrm{~cm}$ intervals.

Sediment accumulation rates (SARs) were determined through complementary ${ }^{210} \mathrm{~Pb}$ and ${ }^{137} \mathrm{Cs}$ analyses. Samples of approximately 20 to $60 \mathrm{~g}$ were taken from 1 -cm-thick intervals. Samples were dried, ground and packed into sealed containers and measured with high-purity germanium gamma detectors (Canberra). The obtained activities were decaycorrected to the date of sampling, and the results are reported within a two- $\sigma$ standard 
deviation uncertainty range. The ${ }^{210} \mathrm{~Pb}$ and ${ }^{137} \mathrm{Cs}$ analyses of the NORTH core were performed in the Department of Marine Chemistry, Institute of Oceanology PAN, whereas the SOUTH core was analysed at the Institute of Geology, Adam Mickiewicz University in Poznań, Poland.

The SARs were calculated from the decrease in excess ${ }^{210} \mathrm{~Pb}$ activity with sediment depth, according to the formula of McKee et al. (1983):

$$
\operatorname{SAR}=\frac{\lambda z}{\ln \frac{A_{0}}{A_{z}}}
$$

where $A_{0}$ is the radionuclide activity in an upper level of the profile, $A_{z}$ is the activity of the radionuclide at distance $\mathrm{z}$ below level $\mathrm{A}_{0}$, and $\lambda$ is the decay constant of the radionuclide $\left(\ln \frac{2}{t_{1 / 2}}\right)$

Changes in the excess ${ }^{210} \mathrm{~Pb}$ activity depth profiles were interpreted as likely changes in the SARs, which were calculated using the same formula. Excess ${ }^{210} \mathrm{~Pb}$ activities were determined by subtracting the average supported activity taken from the sample below the region of radioactive decay from the total activity. Another independent SAR assessment was made using the first occurrence of ${ }^{137} \mathrm{Cs}$ as a marker of the early 1950s (taken as 1952) and its maximum activity as 1962 (e.g. Robbins \& Edgington 1975; Appleby 2008). Due to possible sediment mixing as well as variations in sediment accumulation rates and sediment properties, the calculated sediment accumulation rates must be regarded as approximate values.

Prior to the grain size analyses (fraction $<2 \mathrm{~mm}$ ), samples were freeze-dried, and the grain size was measured with a Mastersizer 2000 laser analyser, coupled with a HydroMU device (Malvern Instruments, UK). The data were analysed using GRADISTAT 8.0 software (Blott \& Pye 2001) and are presented as \% volume. The sediment size fractions were classified according to Udden (1914) and Wentworth (1922). Mean grain size was calculated using the logarithmic method of moments. Furthermore, the dried and weighted fraction $>0.5$ 
mm was used for ice-rafted debris (IRD) analyses. IRD is reported as the number of grains per gram of sediment ( grains $\left.\mathrm{g}^{-1}\right)$.

Ten to twelve well-preserved tests of average size belonging to the foraminiferal species Cibicides lobatulus were selected for stable isotope $\left(\delta^{18} \mathrm{O}\right.$ and $\left.\delta^{13} \mathrm{C}\right)$ measurements from 15 layers of each core. Specimens of similar size were collected from the size fraction $100-500 \mu \mathrm{m}$. Measurements were performed using a Finnigan-MAT 253 mass spectrometer coupled to a Kiel IV carbonate preparation device (Thermo Fischer Scientific, Waltham, MA, USA) at the University of Florida. The resulting values were compared to the isotopic standard NBS-19 and are expressed in standard $\delta$ notation relative to the Vienna Pee Dee Belemnite (VPDB) standard.

Prior to the benthic foraminiferal assemblage analyses, each subsample was dried, weighed and wet sieved using sieves with mesh sizes of 500 and $100 \mu \mathrm{m}$. In total, 300 to 500 specimens were dry-picked from the $>100 \mu \mathrm{m}$ fraction and identified to the most specific taxonomic level possible. Samples with large quantities of tests were divided with a microsplitter prior to counting. The foraminiferal counts are presented as the number of species and as the absolute abundance (number of individuals per gram of sediment; ind. $\mathrm{g}^{-1}$ ) and relative abundance ( $\%$ of the total assemblage).

The foraminiferal species were grouped based on their ecological tolerance, according to Majewski et al. (2009) and references therein. Four groups of indicators (Table 1) were distinguished: glaciomarine species, AW indicators, ArW indicators and bottom-current indicators.

Foraminiferal assemblages were analysed using a multivariate analysis with PRIMER 6.0 software (Clarke \& Warwick 2001). Bray-Curtis similarities between the samples were calculated based on the double root-transformed dataset. Similarity matrices were visualized with a hierarchical cluster plot. The assemblages were analysed by orthogonally rotated 
(varimax) Q-mode Principal Component (PC) analysis using SYSTAT 11 software. Taxa with abundances of $>1 \%$ in at least one sample were analysed. Each PC was defined by the dominant (and eventually accessory) species. The PCs are referred to as foraminiferal assemblages (FA) named after the dominant species.

\section{Results}

\section{Sediment accumulation rates}

The downcore changes and activities of ${ }^{210} \mathrm{~Pb}$ and ${ }^{137} \mathrm{Cs}$ in both cores were similar (Fig. 2). Thus, the average sediment accumulation rate (SAR) is considered similar in both cores and, depending on the applied calculation model, varies between 0.2 and $0.4 \mathrm{~cm} \mathrm{a}^{-1}$, as verified by the maximum ${ }^{137} \mathrm{Cs}$ activity at approximately $20 \mathrm{~cm}$ ascribed to 1961 . In both cores, the excess ${ }^{210} \mathrm{~Pb}$ profile revealed some variations in activity with depth, which could be ascribed to variations in SAR, assuming limited impact of mixing, changing sediment sources, and other effects. In general, a steeper profile likely represents a higher SAR. The SAR in the NORTH core varied from 0.05 to $0.8 \mathrm{~cm} \mathrm{a}^{-1}$ (Fig. 3). There were two distinctive periods when SAR was noticeably higher: between 22 and $16 \mathrm{~cm}$ sediment depth and between 12 and $4 \mathrm{~cm}$ sediment depth. The SAR in the SOUTH core was relatively stable in the lower part of the core (below $15 \mathrm{~cm}$ sediment depth) and did not exceed $0.2 \mathrm{~cm} \mathrm{a}^{-1}$. In the uppermost $15 \mathrm{~cm}$, two possible periods of high SAR occurred, reaching 0.6 and $1.1 \mathrm{~cm} \mathrm{a}^{-1}$, respectively (Fig. 3).

\section{Grain size and IRD}

The sediment in the NORTH core is composed of mud and is dominated by the silt fraction. The sand content is less than $20 \%$ (Fig. 3). The mean grain size was classified as medium to coarse silt. The sediment is poorly sorted throughout and unimodal in the upper $22 \mathrm{~cm}$. The sediment is bimodal between 23 and $30 \mathrm{~cm}$ depth (Fig. 4). The amount of IRD is highest in 
the lowermost part of the core (between 30 and $25 \mathrm{~cm}$ depth), reaching up to 34 grains $\mathrm{g}^{-1}$. However, four marked peaks of IRD also occur at the depths of 20, 17, 7, and $3 \mathrm{~cm}$, with values of up to 31 grains $\mathrm{g}^{-1}$ (Fig. 3).

The sediment recovered in the SOUTH core is composed mostly of silt, with the sand content reaching $14 \%$ (Fig. 3). The mean grain size was classified as medium silt. The sediments are unimodal and poorly sorted throughout the core (Fig. 4). The amount of IRD per gram of sediment decreases towards the top of the core and is highest (up to 23 grains $\mathrm{g}^{-1}$ ) at the bottom of the core. In the uppermost layers, the amount of IRD does not exceed 5 grains $\mathrm{g}^{-1}$ (Fig. 3).

\section{Stable isotopes}

The $\delta^{18} \mathrm{O}$ values of the foraminiferal tests from the NORTH core range from 4.0 to $2.38 \%$ vs. VPDB and are most variable in the lowermost part of the core (between 30 and $20 \mathrm{~cm}$ ), with two peaks of higher $\delta^{18} \mathrm{O}$ values at 25 and $21 \mathrm{~cm}$ depth, which reach values of 3.8 and $4.0 \%$ vs. VPDB, respectively. In the upper layers, the $\delta^{18} \mathrm{O}$ values are lower and more stable, with the lowest $\delta^{18} \mathrm{O}$ value at a sediment depth of $9 \mathrm{~cm}$. The $\delta^{13} \mathrm{C}$ values vary from 1.22 to $-0.24 \%$ vs. VPDB and generally increase upcore, with the lightest $\delta^{13} \mathrm{C}$ occurring between 10 and 5 cm sediment depth (Fig. 3).

In the SOUTH core, the $\delta^{18} \mathrm{O}$ values vary from 3.15 to $2.43 \%$ vs. VPDB and are generally less variable than those in the NORTH core. The $\delta^{18} \mathrm{O}$ values are slightly lower in the upper $15 \mathrm{~cm}$, reaching $2.2 \%$ vs. VPDB in the uppermost sample. The $\delta^{13} \mathrm{C}$ values range from 1.41 to $-0.5 \%$ vs. VPDB, and the variations are similar to those of the $\delta^{18} \mathrm{O}$ values, i.e., lower $\delta^{13} \mathrm{C}$ values are present in the upper part of the core (Fig. 3). 


\section{Foraminiferal abundance and species composition}

A total of 45 benthic foraminiferal taxa were identified in the NORTH core (Table S1). Foraminiferal abundance was low $\left(\leq 607\right.$ ind. $\left.\mathrm{g}^{-1}\right)$ and relatively stable in the sediment layers between 30 and $10 \mathrm{~cm}$. In the upper $10 \mathrm{~cm}$, foraminiferal abundance increased considerably, reaching up to 1600 ind. $\mathrm{g}^{-1}$ (Fig. 5). The number of species per sample varies with depth, decreasing from 26 at $6 \mathrm{~cm}$ to 8 at $25 \mathrm{~cm}$ sediment depths (Fig. 5).

A total of 70 taxa were identified in the SOUTH core (Table S2). The number of foraminifera per gram of sediment is higher than in the NORTH core, and the highest values were noted in the uppermost $15 \mathrm{~cm}$ of sediment (up to 1750 ind. $\mathrm{g}^{-1}$; Fig. 5). The number of species per sample decreases with depth, and the highest values (up to 33 species) were observed in the uppermost $10 \mathrm{~cm}$ (Fig. 5).

The foraminiferal assemblages in both cores are dominated by glaciomarine species (Fig. 5), mainly Elphidium excavatum and Cassidulina reniforme (Tables S1, S2), which account for $90 \%$ of the foraminiferal specimens in the NORTH core and $83 \%$ of those in the SOUTH core. The percentage of glaciomarine species is highest in the lowermost layers of both cores (Fig. 5). The NORTH core is also characterized by a high abundance of bottom current indicators, mainly Cibicides lobatulus (up to 30\%; Fig. 5; Table S1), whereas the SOUTH core is characterized by a high percentage of species considered to be AW indicators (up to $25 \%$ ) and agglutinated taxa (up to $50 \%$; Fig. 5).

The NORTH and SOUTH foraminiferal assemblages formed clearly separate groups on the cluster plot (Fig. 6). In the NORTH core, the 3 -factor PC explained $97.76 \%$ of the total variance of the tested dataset (Fig. 7, Table 2). The statistically important assemblages are (1) the C. reniforme Foraminiferal Assemblage (FA), with C. lobatulus and E. excavatum as accessory species, which explains $91.91 \%$ of the total variance, (2) the E. excavatum FA, with C. reniforme and C. lobatulus as accessory species, which explains $3.64 \%$ of the variance, and 
(3) the C. lobatulus FA, with C. reniforme and Cribrostomoides crassimargo as accessory species, which explains $2.21 \%$ of the variance (Table 2). In the SOUTH core, the proposed 4factor PC explains $96.73 \%$ of the total variance. The statistically important assemblages are (1) the C. reniforme FA, with Spiroplectammina biformis and Bucella frigida as accessory species, which explains $37.38 \%$ of the total variance, (2) the E. excavatum FA, with $S$. biformis, Recurvoides turbinatus, Nonionellina labradorica, B. frigida and Islandiella norcrossi as accessory species, which explains $29.93 \%$ of the variance, (3) the $R$. turbinatus FA, with E. excavatum, C. reniforme, and B. frigida as accessory species, which explains $17.69 \%$ of the total variance, and (4) the N. labradorica FA, with E. excavatum, S. biformis, Spiroplectammina earlandi, C. reniforme, and Hyperammina subnodosa as accessory species, which explaines $11.72 \%$ of the total variance (Table 3 ). Both cores are dominated throughout by the $C$. reniforme FA and E. excavatum FA. In the NORTH core, the C. lobatulus FA loadings are the highest in the lowermost $10 \mathrm{~cm}$. In the SOUTH core, the $R$. turbinatus FA becomes significant between 18 and $5 \mathrm{~cm}$ sediment depth, and the $N$. labradorica FA becomes significant at $\sim 23 \mathrm{~cm}$ and in the uppermost $3 \mathrm{~cm}$ of sediment (Fig. 7).

\section{Discussion}

\section{Sedimentary environment}

No substantial differences between the cores are observed in terms of the mean grain size and the grain size composition (Fig. 4). Moreover, the measured ${ }^{210} \mathrm{~Pb}$ activities and, consequently, the calculated average sediment accumulation rate (SAR) are similar, prompting the comparison of the NORTH and SOUTH sedimentary records in terms of the influence of the Coriolis force on the sedimentary regime in Hornsund. We hypothesize that long-term variations in the deposits in the SOUTH core reflect the influence of shelf processes related to regional oceanographic changes (e.g., the balance between Arctic and 
Atlantic water masses), whereas the record from the NORTH core reflects a combination of regional oceanographic changes as well as local influences of meltwater runoff originating from the numerous glaciers in the inner fjord.

The most pronounced sign of glacial impact on the NORTH core is the markedly higher and more variable IRD delivery during the 20th century compared to the SOUTH core (Fig. 3). Svalbard glaciers reached their maximum Holocene extent at the end of the Little Ice Age (LIA; AD 1900, Majewski et al. 2009) and retreated during the 20th century (Plassen et al. 2004; Błaszczyk et al. 2013). At the end of the 19th century, both coring sites were located closer to the potential sources of icebergs (e.g., the glaciers Hansbreen and Körberbreen; Fig. 1B). In the SOUTH core, the continuously decreasing amount of IRD (Fig. 3) since $\sim A D$ 1900 is suggested to reflect the increasing distance between the calving fronts of tidewater glaciers and the coring site and the consequent reduction in drifting icebergs and IRD transport. Conversely, the higher and more variable IRD delivery observed in the NORTH core throughout the 20th century reflects the continuous glacial impact on the site. This may be due to the much closer proximity of the Hansbreen tidewater glacier calving front but may also result from the position of the site on the primary transport path of icebergs from the inner fjord due to Coriolis force-induced circulation. The onset of the 20th century is also marked by variable $\delta^{18} \mathrm{O}$ values in the NORTH core, whereas the $\delta^{18} \mathrm{O}$ values in the SOUTH core remain relatively stable (Fig. 3). The variability in the NORTH record might indicate the strong seasonal influence of meltwater delivered during the summer from retreating glaciers.

Moreover, the bimodal grain size distribution occurring at the onset of the 20th century in the NORTH core may also be attributed to the glacial impact, including an additional sediment source (e.g. a meltwater stream) or more intense ice rafting (Fig. 4). It is less probable that sediment bimodality resulted from sediment sorting, as the sediments are poorly sorted throughout the core. However, the grain-size distribution in fjords might be 
controlled also by other factors, such as gravity flows and turbidity currents (Elverhøi et al. 1983), ice-contact processes in front of tidewater glaciers, and tidal currents in the outer fjord (Syvitski 1989). Thus the variety of factors possibly impacting the sediment grain-size distribution precludes reaching any general conclusions.

The $\delta^{13} \mathrm{C}$ records in the two cores reveal a similar increasing trend from the onset of the 20th century to the present (Fig. 3). These changes may be related to the spring sea-ice extent and primary production. According the Vinje et al. (2001), the April sea-ice extent was reduced by approximately $33 \%$ during the last 130 years. The presence of sea-ice cover in spring causes i) a reduction of the thickness of the euphotic zone, ii) a higher concentration of phytoplankton biomass in the upper layer of surface meltwater, and iii) a change in the timing of the spring phytoplankton bloom. In ice-free years, the spring phytoplankton bloom starts earlier, and the phytoplankton biomass is spread throughout the entire water column (Zajączkowski et al. 2010b). Additionally, meltwater and sediment delivery to the fjord affects the turbidity of the euphotic zone, limiting primary production and the flux of fresh organic matter to the bottom (Zajączkowski et al. 2010b). In Hornsund, the glaciers retreated during the 20th century, and the majority of the meltwater and suspended material delivery likely became restricted to the inner glacier bays. Thus, we suggest that the observed trend in the $\delta^{13} \mathrm{C}$ records reflects the shift from an environment impacted by sea ice and glacial activity to modern ice-free conditions with lower concentrations of suspended material in the main fjord basin.

\section{Foraminiferal fauna}

The foraminiferal assemblages in the two cores are dominated throughout by two glaciomarine species, E. excavatum and C. reniforme (Figs. 5, 7), in agreement with previous studies of foraminiferal fauna in Hornsund (e.g. Hald \& Korsun 1997; Zajączkowski et al. 
2010a). The presence of E. excavatum and $C$. reniforme is usually attributed to settings characterized by high sedimentation rates, pulsed organic matter supplies and unstable bottom sediments (Korsun et al. 1995; Hald \& Korsun 1997; Pogodina 2005; Jernas 2012). Notably, in the periods of stronger dominance of $C$. reniforme (expressed as PC loading values), the significance of E. excavatum decreases, and vice versa. E. excavatum and C. reniforme occur frequently in modern glaciomarine environments; however, it is likely that $C$. reniforme prefers higher salinities compared to E. excavatum (Jernas 2012), such as the conditions present during seasons of stronger AW influence in the fjord (Lącka \& Zajączkowski 2016).

Despite the fact that the foraminiferal fauna in both studied cores are dominated by $E$. excavatum and $C$. reniforme, the NORTH and SOUTH cores form clearly separated assemblages on the cluster plot (Fig. 6). The most characteristic features of the NORTH foraminiferal assemblages are the overall low numerical abundance and species diversity and a low percentage of agglutinated fauna, which are features characteristic of glacier-proximal sites impacted by brackish, turbid water. Additionally, an increased percentage of bottom current indicators, which require attachment to a hard substrate, are observed, and their presence can be attributed to the occurrence of high amounts of IRD (Fig. 5). A decrease in species richness and faunal density was previously observed in the vicinity of glaciers in the Spitsbergen fjords (e.g. Jernas 2012; Włodarska-Kowalczuk et al. 2013). Another feature characteristic of glacier-impacted environments is the low percentage of agglutinated taxa (Hald \& Korsun 1997), which in the NORTH core does not exceed 5\% and reaches the lowest values prior to $\sim \mathrm{AD} 1960$ (Fig. 5). The low percentages of agglutinated species in the lowermost parts of the core might therefore be the result of both the environmental change associated with the glacial retreat and the natural degradation of fragile agglutinated tests. Moreover, the NORTH core is characterized by a high percentage of bottom current indicators, mainly C. lobatulus (Fig. 5), which is an epiphytic species that requires a hard 
substrate to stay attached to the bottom surface. In the NORTH core, the C. lobatulus FA become markedly important during periods of increased IRD delivery (Figs. 5, 7).

In contrast, changes in the foraminiferal species composition, diversity and abundance in the SOUTH core reflect the inflow of STW rather than the activity of tidewater glaciers. The SOUTH core foraminiferal assemblage is characterized by a high percentage of species classified as AW and ArW indicators (Fig. 5). Moreover, the total number of species recorded in the SOUTH core is significantly higher than in the NORTH core (Tables S1, S2). In the SOUTH core, the number of foraminiferal assemblages (FA) is higher, and the difference between the score values of dominant and accessory species are lower than in the NORTH core (Fig. 7; Tables 2, 3). These results clearly show that the foraminiferal community in the SOUTH core is more diverse than in the NORTH core. The observed difference in foraminiferal diversity might be due to the large number of rare species (i.e., species that account for $<1 \%$ of the total abundance) in the SOUTH core (Table S2). Lacka \& Zajączkowski (2016) noted that the increased inflow of shelf-originated STW results in higher foraminiferal biodiversity and a higher number of rare species. However, many of them have small, fragile tests that are poorly preserved in the fossil record. The presence of high numbers of DNA sequences assigned to species that are considered rare in Hornsund from a sediment core collected near the SOUTH site supports this assumption (Pawłowska et al. 2014).

Another typical feature of the environments influenced by Atlantic water are the high abundance of $N$. labradorica and increased percentage of agglutinated taxa. According to Hald \& Korsun (1997), the N. labradorica FA is among the most characteristic foraminiferal assemblages of Spitsbergen. It occupies the outer parts of the Spitsbergen fjords influenced by water masses of Atlantic origin. In the SOUTH core, the N. labradorica FA is observed, but its significance is minor (Fig. 7). This may be due to the high percentage of agglutinated 
foraminifera (up to 50\%; Fig. 5) in this core. Hald \& Korsun (1997) noted that when agglutinated taxa are excluded from the dataset, the dominant calcareous foraminiferal assemblages remain the same, but the relative importance of $N$. labradorica FA increases. Moreover, such a high percentage of agglutinated foraminifera is typical of glacier-distal sites. In general, in the western Spitsbergen fjords, the proportion of agglutinated foraminifera increases from the glaciated head towards the fjord mouth, and assemblages dominated by agglutinated species in particular occupy the central and outer parts of the fjords (Hald \& Korsun 1997; Forwick et al. 2010).

The last century was characterized by a rapid climate warming followed by glacial retreat (Ziaja 2001; Pälli et al., 2001) Although both coring stations were located close to tidewater glacier fronts at the beginning of the $20^{\text {th }}$ century, the glacial impact was much more pronounced in the NORTH core, which can be attributed to the influence of the Coriolis force. In western Spitsbergen fjords, the Coriolis force drives the majority of shelf water entering the fjord to be transported mainly along the southern shore, whereas the local water (including glacial meltwater) is guided along the northern shore towards the fjord mouth. Strong winds can disturb this pattern by shifting the brackish water plume to the opposite shore, but, in general, lower salinity and higher sedimentation conditions predominate along the northern part of the fjord (e.g., Svendsen et al. 2002; Nilsen et al. 2008). These processes result in spatial gradients in the environmental conditions, which might be especially sharp in Hornsund, where major tidewater glaciers are located in the northern part of the fjord.

The influence of rotational dynamics on fjord environments was previously observed in Spitsbergen fjords, e.g., Isfjorden (Nilsen et al. 2008), Kongsfjorden (Svendsen et al. 2002) and Storfjorden (Skogseth et al. 2005). The influence of the Coriolis force in Arctic fjords is pronounced due mainly to the fjord widths, which exceed the Rossby radius. The internal Rossby radius of deformation is a measure of the relative importance of stratification vs. 
rotation: a Rossby radius that is smaller than the fjords width allows for the variation in the flow induced by rotational dynamics (Cottier et al. 2010). Moreover, the majority of European Arctic fjords are oriented east-west, and their inner areas are impacted by glacial/fluvial water, whereas the outer areas are located near the major AW pathway to the Arctic Ocean. Therefore, the environmental effects of Coriolis force-driven circulation observed in Hornsund may serve as a model and may be applied to the other fjords in the region.

\section{Conclusions}

The influence of the Coriolis force-driven rotational dynamics is recognized in the studied cores, which were collected in the southern and northern parts of a fjord at similar water depths and distances from land. The influence of the Coriolis force on the sedimentary and hydrological regime is most clearly visible in the grain size and IRD records. During the last century, the glacial impact on central Hornsund progressively diminished during the retreat of major tidewater glaciers to the inner bays. Therefore, the glacial influence, expressed as higher variability in the grain size, IRD content, and $\delta^{18} \mathrm{O}$ values, is recorded in southern Hornsund only in the late 19th and early 20th centuries, whereas the impact of glaciers has been continuously recorded in the northern part of the fjord for the last 100 years. This impact on northern Hornsund is likely due to the more effective local meltwater supply and iceberg drift, both of which are preferentially driven along the northern coast. However, further studies are required to provide more robust conclusions.

The influence of the Coriolis force is also clearly visible in the foraminiferal assemblages. Despite the overall dominance of two glaciomarine species, namely $E$. excavatum and C. reniforme, the foraminiferal fauna from the two Hornsund cores spanning the last century exhibit clearly distinct assemblages, as revealed by cluster analysis. Southern Hornsund was influenced mainly by shelf-derived water masses of mixed Arctic and Atlantic 
origin. This influence is expressed as markedly higher species diversity and by a higher proportion of Atlantic water species on the southern side compared to the northern side of Hornsund. Moreover, the high number of rare species may imply a constant introduction of species from offshore pools (i.e., from the West Spitsbergen shelf). In contrast, the northern part of Hornsund was more heavily influenced by local waters and glacial meltwater. This influence is reflected in the lower foraminiferal diversity and the dominance of glaciomarine fauna and bottom current indicators.

The important insight of this study is that the Coriolis effect, which is rarely considered in palaeoenvironmental studies of fjord sediments, may be very important in the context of coring site selection. Coring sites selected along the fjord axis likely represent average environmental conditions. Thus, to better target the oceanic input or glacial response, one should consider sediment sampling based on the major Coriolis-induced circulation pattern.

Acknowledgements. This paper is a contribution to the QUAL-project funded by the Academy of Finland (grant no. 259343). This study was developed within the framework of grants no. 2011/01/N/ST10/06533, 2013/10/E/ST10/00166, and 2014/12/T/ST10/00675 funded by the National Science Centre in Kraków (Poland), and Brian J. O’Neill Memorial Grant-in-Aid funded by Grzybowski Foundation. We thank the crews and participants of the cruises on R/V Oceania crew and R/V Jan Mayen, in particular Steinar Iversen for their help during the fieldwork. The authors thank Anna Pieńkowski and an anonymous Reviewer for their constructive reviews which helped to improve the manuscript. 


\section{References}

Andrews, J. T. \& Syvitski, J. P. M. 1994: Sediment fluxes along high latitude glaciated continental margins: Northeast Canada and Eastern Greenland. In Global Sedimentary Geofluxes, 99-115, National Research Council and National Academy of Sciences Press, Washington D.C.

Appleby, P. G. 2008: Three decades of dating recent sediments by fallout radionuclides: a review. The Holocene 18, 83-93.

Berge, J., Johnsen, G., Nilsen F., Gulliksen, B. \& Slagstad D. 2005: Ocean temperature oscillations enable reappearance of blue mussels Mytilus edulis in Svalbard after a 1000 year absence. Marine Ecology Progress Series 303, 167-175.

Beszczyńska-Möller, A., Węsławski, J. M., Walczowski, W. \& Zajączkowski, M. 1997: Estimation of glacial meltwater discharge into Svalbard coastal waters. Oceanologia 39, 289298.

Błaszczyk, M., Jania, J. \& Kolondra, L. 2013: Fluctuations of tidewater glaciers in Hornsund Fjord (Southern Svalbard) since the beginning of the $20^{\text {th }}$ century. Polish Polar Research 34 , $327-352$.

Blott, S. J. \& Pye, K. 2001: GRADISTAT: a grain size distribution and statistics package for the analysis of unconsolidated sediments. Earth Surface Processes and Landforms 26, 1237 1248.

Clarke, K. R. \& Warwick, R. M. 2001: Change in marine communities: an approach to statistical analysis and interpretation. 172 pp. PRIMER-E, Plymouth.

Cottier, F., Tverberg, V., Inall, M., Svendsen, H., Nilsen, F. \& Griffiths, C. 2005: Water mass modification in an Arctic fjord through cross-shelf exchange: The seasonal hydrography of Kongsfjorden, Svalbard. Journal of Geophysical Research: Oceans 110, C12005, doi:10.1029/2004JC002757. 
Cottier, F. R., Nilsen, F., Skogseth, R., Tverberg, V., Skardhamar, J. \& Svendsen, H. 2010: Arctic fjords: a review of the oceanographic environment and dominant physical processes. In Howe, J. A., Austin, W. E. N., Forwick, M. \& Paetzel, M. (eds.): Fjords Systems and Archives 344, 35-50, Geological Society, London, Special Publications.

Dallimore, A., Enkin, R. J., Pienitz, R., Southon, J. R., Baker, J., Wright, C. A., Pedersen, T. F., Calvert, S. E., Ivanochko, T. \& Thomson. R. E. 2008: Postglacial evolution of a Pacific coastal fjord in British Columbia, Canada: interactions of sea-level change, crustal response, and environmental fluctuations - results from MONA core MD02-2494. Canadian Journal of Earth Sciences 45, 1345-1362.

Elverhøi, A., Lonne, Ø. \& Seland, R. 1983: Glaciomarine sedimentation in a modern fjord environment. Polar Research 1, 127-149.

Forwick, M., Vorren, T. O., Hald, M., Korsun, S., Roh, Y., Vogt, C. \& Yoo K-Y. 2010: Spatial and temporal influence of glaciers and rivers on the sedimentary environment in Sassenfjorden and Tempelfjorden, Spitsbergen. In Howe, J. A., Austin, W. E. N., Forwick, M. \& Paetzel, M. (eds.) Fjords Systems and Archives 344, 165-195. Geological Society, London, Special Publications.

Gilbert, R. 1983: Sedimentary process of Canadian arctic fjords. Sedimentary Geology 36, $147-175$

Gilbert, R., Nelson, N., Desloges, J. \& Rasch, M. 1998: Contrasting glaciomarine sedimentary environments of two arctic fjords on Disco, West Greenland. Marine Geology 147, 63-83.

Gilbert, R. 2000: Environmental assessment from the sedimentary record of high-latitude fjords. Geomorphology 32, 295-314. 
Gilbert, R., Chong, Å., Dunbar, R. B. \& Domack, E. W. 2003: Sediment trap records of glacimarine sedimentation at Müller Ice Shelf, Lallemand Fjord, Antarctic Peninsula. Arctic, Antarctic and Alpine Research 35, 24-33.

Görlich, K. 1986: Glacimarine sedimentation of muds in Hornsund fjord, Spitsbergen. Annales Societatis Geologorum Poloniae 56, 433-477.

Hagen, J. O., Liestøl, O., Roland, E. \& Jørgensen, T. 1993: Glacier atlas of Svalbard and Jan Mayen. 169 pp. Meddelelser no. 129, Oslo.

Hald, M. \& Korsun, S. 1997: Distribution of modern benthic foraminifera from fjords of Svalbard, European Arctic. Journal of Foraminferal Research 27, 101-122.

Hansen, A. \& Knudsen, K.L. 1992: Recent foraminifera in Freemansundet, eastern Svalbard. LUNDQUA Report 35, 177-189.

Howe, J. A., Moreton, S. G., Morri, C. \& Morris, P. 2003: Multibeam bathymetry and the depositional environment of Kongsfjorden and Krossfjorden, western Spitsbergen, Svalbard. Polar Research 22, 301-316.

Jernas, P., 2012: Benthic foraminifera in an Arctic fjord: recent distribution and fauna of the last two millennia. Ph.D. Thesis, 116 pp. University of Tromsø, Norway.

Jernas, P., Klitgaard-Kristensen, D., Husum, K., Wilson, L. \& Koç, N., 2013: Paleoenvironmental changes of the last two millennia on the western and northern Svalbard shelf. Boreas 42, 236-255.

Kelly, M., Funder, S., Houmark-Nielsen, M., Knudsen, K. L., Kronborg, C., Landvik, J., Sorby, L. 1999: Quaternary glacial and marine environmental history of northwestern Greenland: a review and reappraisal. Quaternary Science Reviews 18, 373-392.

Korsun, S. \& Hald, M. 2000: Seasonal dynamics of benthic foraminifera in a glacially fed fjord of Svalbard, European Arctic. Journal of Foraminiferal Research 30, 251-271 
Korsun, S., Pogodina, S. L., Forman, S. L. \& Lubiński, D. J. 1995: Recent foraminifera in glaciomarine sediments from three arctic fjords of Novaja Zemlja and Svalbard. Polar Research 14, 15-31.

Korsun, S., \& Hald, M. 1998: Modern benthic foraminifera of Novaya Zemlya tidewater glaciers, Russian Arctic. Arctic, Antarctic and Alpine Research 30, 61-77.

Lloyd, J. M. 2006: Modern distribution of benthic foraminifera from Disko Bugt, West Greenland. Journal of Foraminiferal Research 36, 315-331.

Lloyd, J. M., Kuijpers, A., Long, A. J., Moros, M., \& Park, L. A. 2007: Foraminiferal reconstruction of mid- to late-Holocene ocean circulation and climate variability in Disko Bugt, West Greenland. The Holocene 17, 1079-1091.

Łącka, M. \& Zajączkowski, M. 2016: Does the recent pool of benthic foraminiferal tests in fjordic surface sediments reflect interannual environmental changes? The resolution limit of the foraminiferal record. Annales Societatis Geologorum Poloniae 86, 59-71.

Majewski, W. \& Zajączkowski, M. 2007: Benthic foraminifera in Adventfjorden, Svalbard: Last 50 years of local hydrographic changes. Journal of Foraminiferal Research 37, 107-124. Majewski, W., Szczuciński, W. \& Zajączkowski M. 2009: Interaction of Arctic and Atlantic water-masses and associated environmental changes during the last millenium, Hornsund (SW Svalbard). Boreas 38, 529-544.

McKee, B. A., Nittrouer, C. A. \& DeMaster, D. J. 1983: Concepts of sediment deposition and accumulation applied to the continental shelf near the mouth of the Yangtze River. Geology 11: 631-633.

Nilsen, F., Cottier, F., Skogseth, R. \& Mattson, S. 2008: Fjord-shelf exchanges controlled by ice and brine production: the interannual variation of Atlantic Water in Isfjorden, Svalbard. Continental Shelf Research 28, 1838-1853. 
Pälli, A., Moore, J. C., Jania, J. \& Głowacki, P. 2003: Glacier changes in southern Spitsbergen, Svalbard, 1901-2000. Annals of Glaciology 37, 219-225.

Pawłowska, J., Lejzerowicz, F., Esling, P., Szczuciński, W., Zajączkowski, M. \& Pawlowski, J. 2014: Ancient DNA sheds new light on the Svalbard foraminiferal fossil record from the last millennium. Geobiology 12, 277-288.

Pawłowska, J., Włodarska-Kowalczuk, M., Zajączkowski, M., Nygård, H. \& Berge J. 2011: Seasonal variability of meio- and macrobenthic standing stocks and diversity in an Arctic fjord (Adventfjorden, Spitsbergen). Polar Biology 34, 833-845.

Plassen, L., Vorren, T. O. \& Forwick, M. 2004: Integrated acoustic and coring investigation of glacigenic deposits in Spitsbergen fjords. Polar Research 23, 89-110.

Pogodina, I. A. 2005: Benthic Foraminifera in Hornsund fjord (West Spitsbergen). Oceanology 45, 559-566.

Polyak, L., Korsun, S., Febo, L. A., Stanovoy, V., Khusid, T., Hald, M., Paulsen, B. E. \& Lubinski, D. J. 2002: Benthic foraminiferal assemblages from the southern Kara Sea, a riverinfluenced Arctic marine environment. Journal of Foraminiferal Research 32, 252-273.

Robbins, J. A. \& Edgington D. N. 1975: Determination of recent sedimentation rates in Lake Michigan using Pb-210 and Cs-137. Geochimica et Cosmochimica Acta 39, 285-304.

Seidenkrantz, M.-S., Aagaard-Sørensen, S., Sulsbrück, H., Kuijpers, A., Jensen, K. G. \& Kunzendorf H. 2007: Hydrography and climate of the last 4400 years in a SW Greenland fjord: implications for Labrador Sea palaeoceanography. The Holocene 17, 387-401.

Sepúlveda, J., Pantoja, S., Hughen, K. A., Bertrand, S., Figueroa, D., León, T., Dreznek, N. J. \& Lange, C. 2009: Late Holocene sea-surface temperature and precipitation variability in northern Patagonia, Chile (Jacaf Fojrd, 44º S). Quaternary Research 72, 400-409. 
Skarðhamar, J. \& Svendsen, H. 2010: Short-term hydrographic variability in a stratified Arctic fjord. In Howe, J. A., Austin, W. E. N., Forwick, M., Paetzel, M. (eds.) Fjords systems and archives 344, 51-60. Geological Society, London, Special Publications.

Skirbekk, K., Klitgaard - Kristensen, D., Rasmussen, T. L., Koç, N. \& Forwick M. 2010: Holocene climate variations at the entrance to a warm Arctic fjord: evidence from Kongsfjorden through, Svalbard. In Howe, J. A., Austin, W. E. N., Forwick, M., Paetzel, M. (eds.) Fjords systems and archives 344, 289-304. Geological Society, London, Special Publications.

Skogseth R., Haughan P. M., Jakobsson M. 2005: Watermass transformations in Storfjorden. Continental Shelf Research 25, 667-695.

Svendsen, H., Beszczyńska-Möller, A., Hagen, J. O., Lefauconnier, B., Tverberg, V., Gerland, S., Ørbæk B. J., Bischof, K., Papucci, C., Zajączkowski, M., Azzolini, R., Bruland, O., Wiencke, C., Winther, J-G. \& Dallmann, W. 2002: The physical environment of Kongsfjorden-Krossfjorden, an Arctic fjord system in Svalbard. Polar Research 21, 133-166.

Syvitski, J. P. M. 1989: On the deposition of sediment with glacier-influenced fjords: oceanographic controls. Marine Geology 85, 301-329.

Szczuciński, W., Schellter, G., \& Zajączkowski, M. 2006: Sediment accumulation rates, geochemistry and provenance in complex High Arctic fjord, Hornsund, Svalbard. Fourth ESF SED- 15IFLUX Science Meeting \& First Workshop of I.A.G./A.I.G. SEDIBUD: Source-toSink-Fluxesand Sediment Budgets in Cold Environmnets, NGF Abstracts and Proceedings of the Geological Society of Norway 4, p.65.

Ślubowska, M. A., Koç, N., Rasmussen, T. L. \& Klitgaard-Kristensen, D. 2005: Changes in the flow of Atlantic water into the Arctic Ocean since the last deglaciation: Evidence from the northern Svalbard continental margin, $80^{\circ} \mathrm{N}$. Paleoceanography 20, PA4014, doi:10.1029/2005PA001141. 
Vinje, T. 2001: Anomalies and trends of sea-ice extent and atmospheric circulation in the Nordic Seas during the period 1864-1998. Journal of Climate 14, 255-267.

Węsławski, J. M., Jankowski, A., Kwaśniewski, S., Swerpel, S. \& Ryg M. 1991: Summer hydrology and zooplankton in two Svalbard fjords. Polish Polar Research 12, 445-460.

Włodarska-Kowalczuk, M., Pawłowska, J., Zajączkowski, M. 2013: Do foraminifera mirror diversity and distribution patterns of macrobenthic fauna in Arctic glacial fjord? Marine Micropaleontology 103, 30-39.

Zajączkowski, M., Szczuciński, W., Plessen, B. \& Jernas, P. 2010a: Benthic foraminifera in Hornsund, Svalbard: Implications for paleoenvironmental reconstructions. Polish Polar Research 31, 349-375.

Zajączkowski, M., Nygård, H., Hegseth, E. N. \& Berge, J. 2010b: Vertical flux of particulate matter in an Arctic fjord: the case of lack of the sea-ice cover in Adventfjorden 2006 - 2007. Polar Biology 33, 223-239.

Ziaja, W. 2001: Glacial recession in Sørkappland and central Norsenskiöldland, Spitsbergen, Svalbard, during the $20^{\text {th }}$ century. Arctic, Atlantic and Alpine Research 33, 36-41. 


\section{Figures captions}

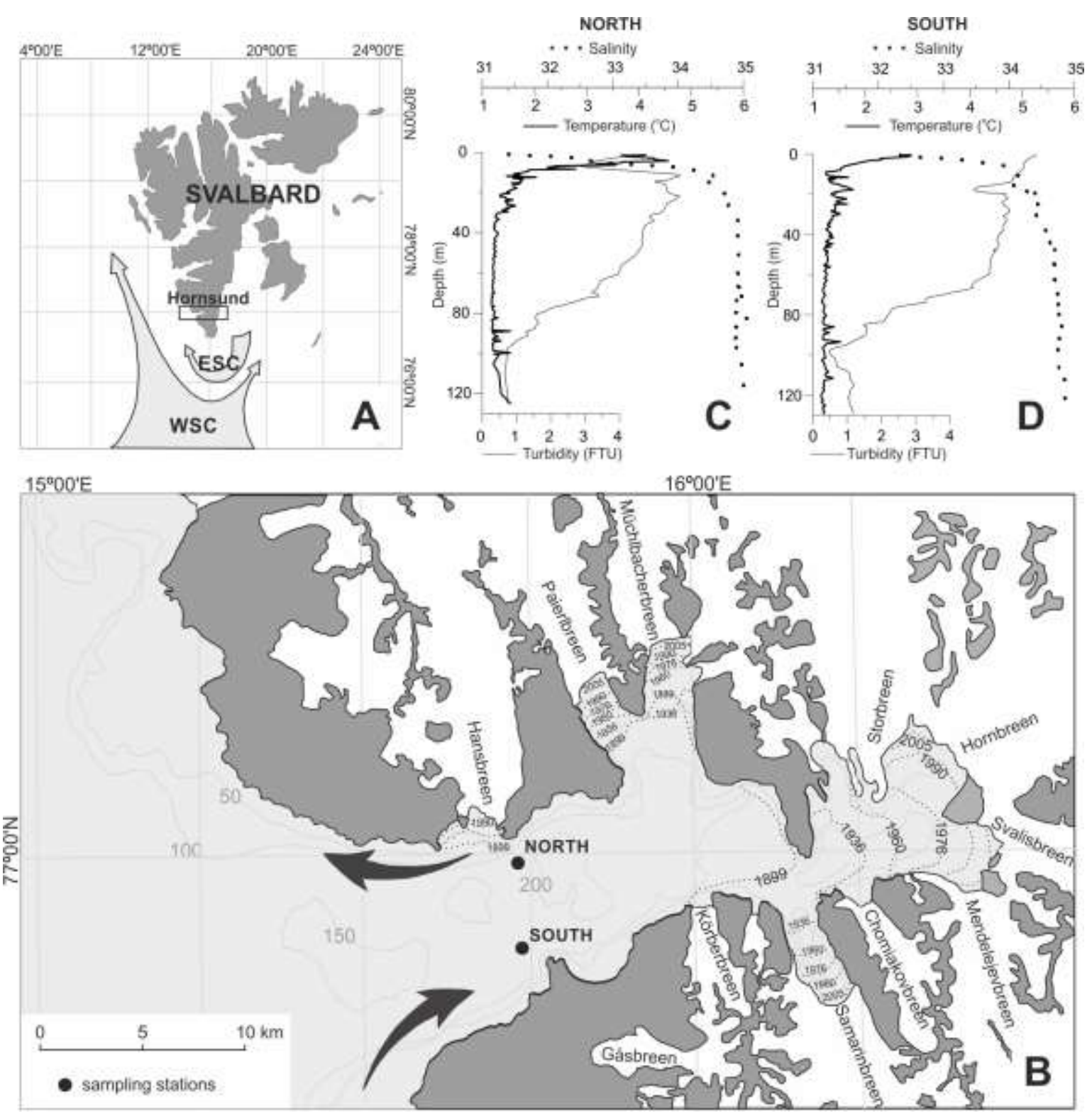

Figure 1. Study area with core locations. Post-LIA glacier-frontal positions (after Pälli et al. 2003) are marked with dashed lines. The direction of water flow induced by the Coriolis force is marked with black arrows (B). CTD data for the NORTH (C) and SOUTH (D) from summer 2012 is presented. WSC = West Spitsbergen Current; ESC = East Spitsbergen Current. 

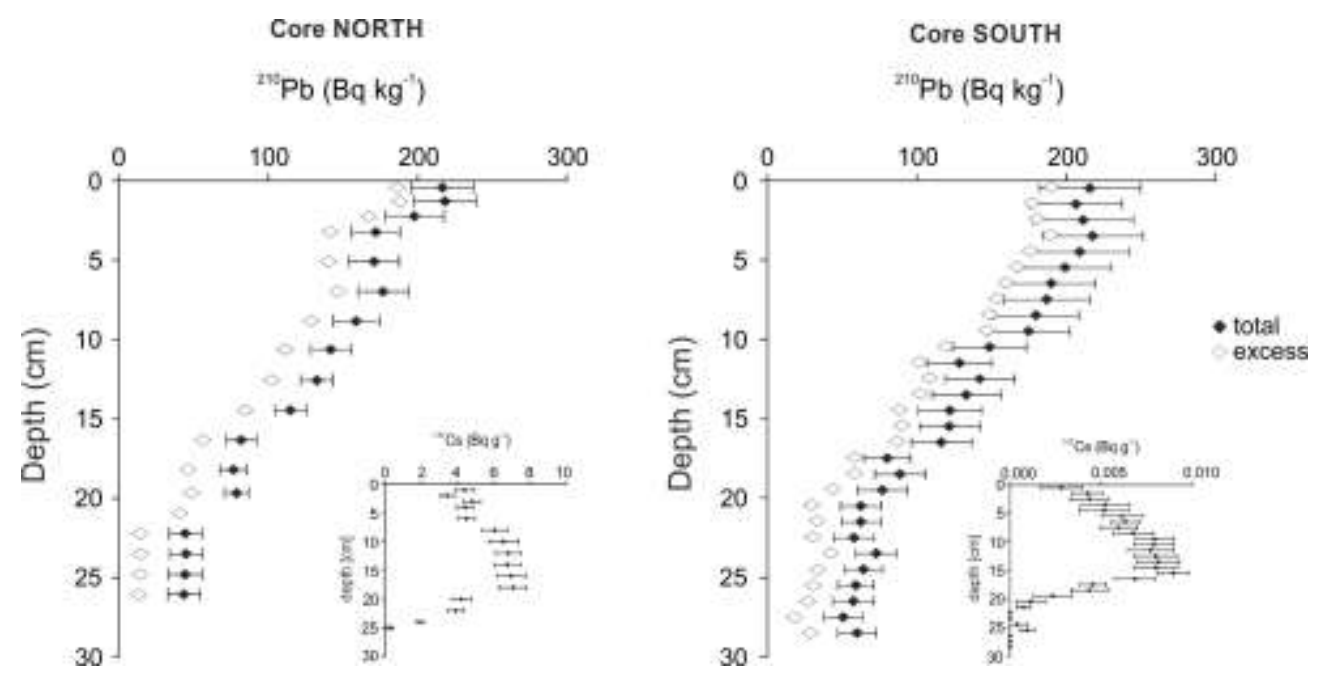

Figure 2. Total and excess ${ }^{210} \mathrm{~Pb}$ and ${ }^{137} \mathrm{Cs}$ activity in the studied cores.

Core NORTH
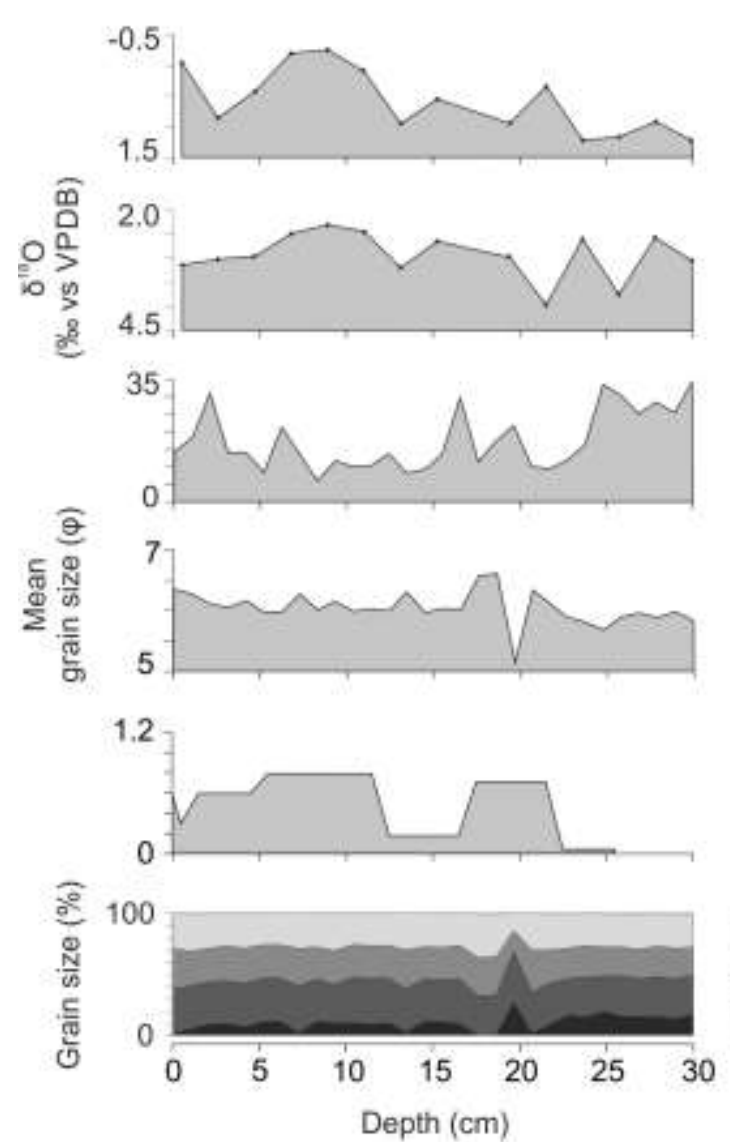

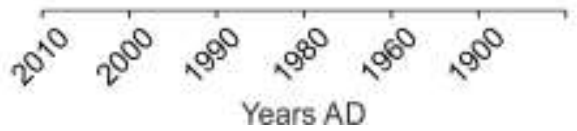

Core SOUTH
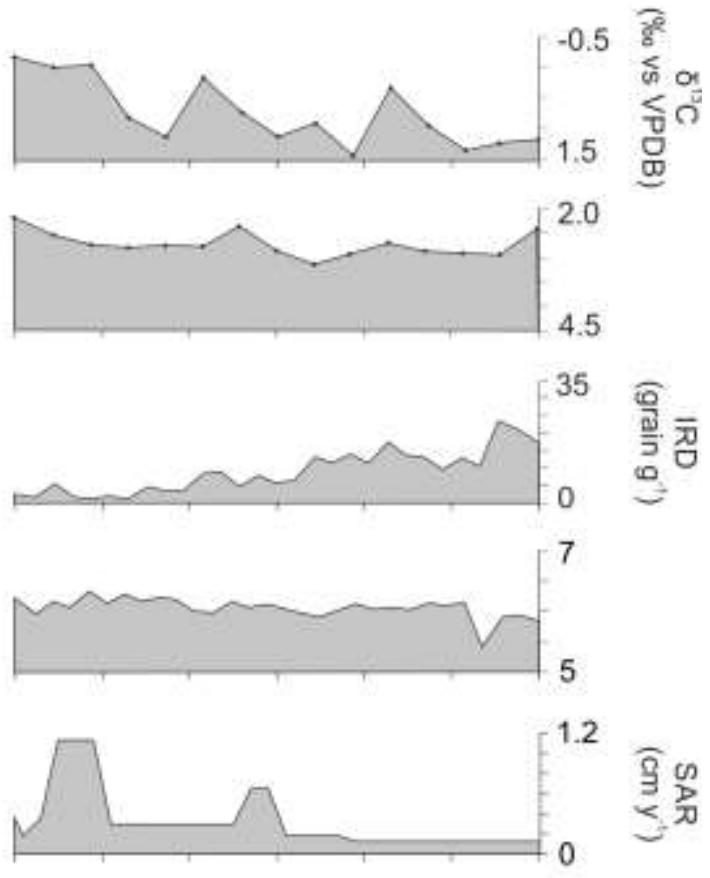

Clay

Fine silt

nedium silt

- Coarse silt

- Sand

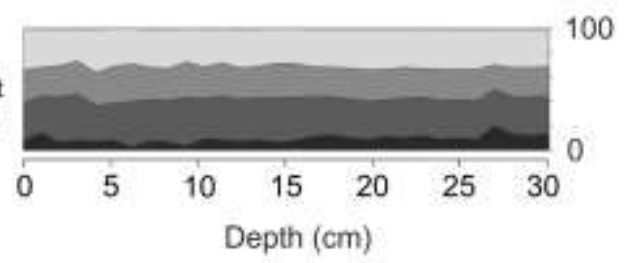

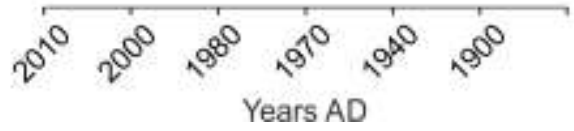


Figure 3. Foraminiferal oxygen $\left(\delta^{18} \mathrm{O}\right)$ and carbon $\left(\delta^{13} \mathrm{C}\right)$ stable isotopes, ice rafted debris (IRD), mean grain size, sediment accumulation rate (SAR), and sediment grain size composition vs. time. Note that the age model has an accuracy of approximately \pm 5 years at approximately $20 \mathrm{~cm}$ sediment depth and it increases with age.

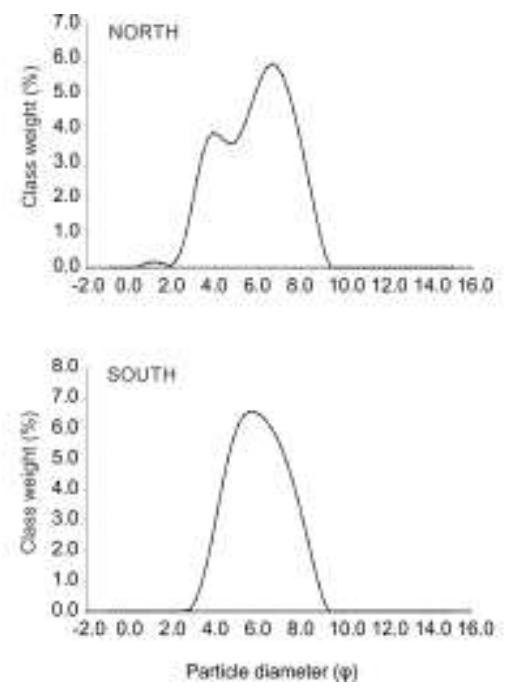

Figure 4. Grain size distribution in the NORTH and SOUTH cores. 


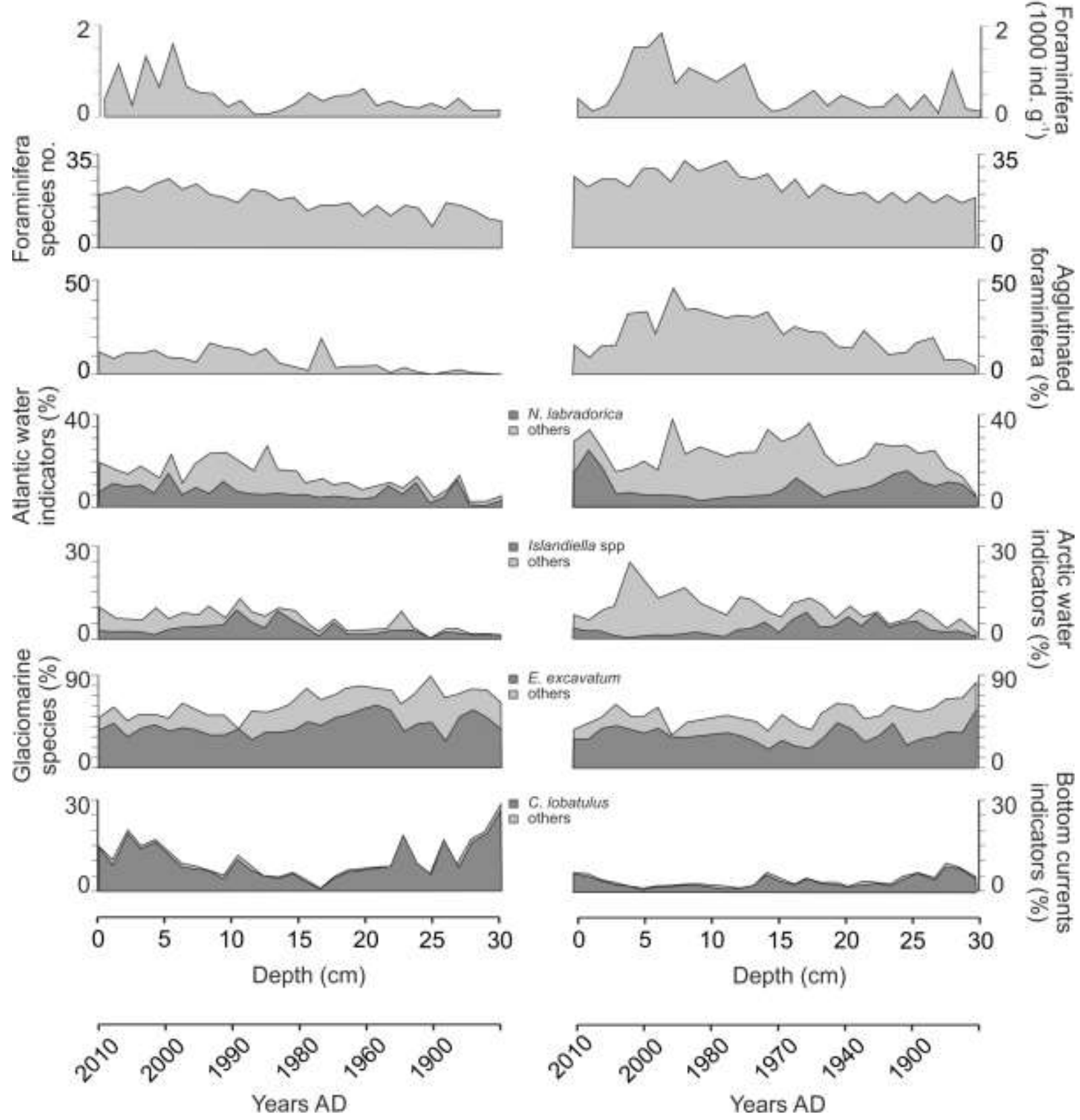

Figure 5. Relative abundances (expressed as \% of the total assemblage) of bottom current indicators, glaciomarine species, Arctic water indicators, Atlantic water indicators, agglutinated species, number of benthic foraminiferal species, and number of benthic foraminiferal tests per gram of sediment vs. time. Foraminifera are grouped according to the classification of Majewski et al. (2009). 


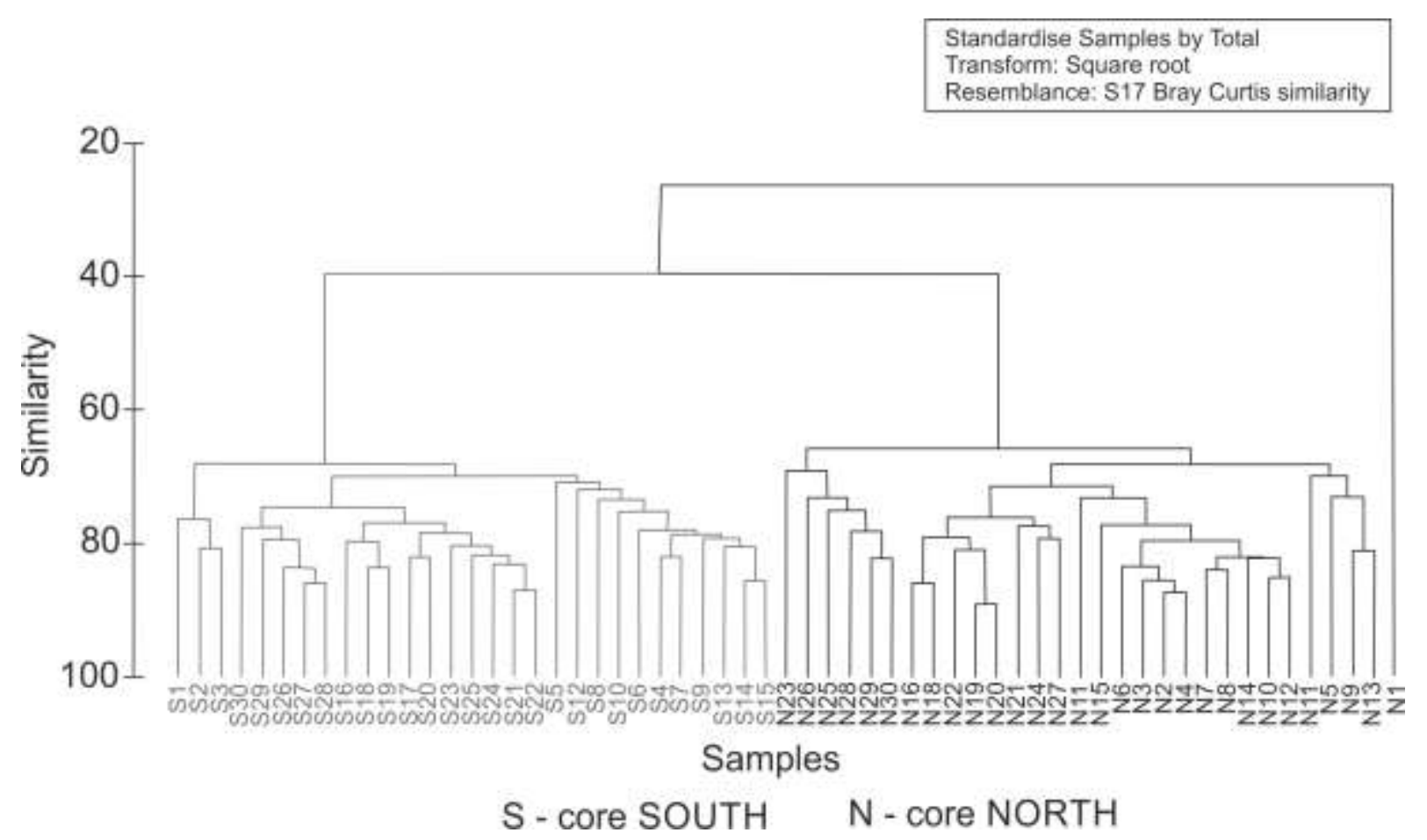

Figure 6. Cluster plot for Bray-Curtis similarities of foraminiferal assemblages between the samples of the NORTH and SOUTH cores. 

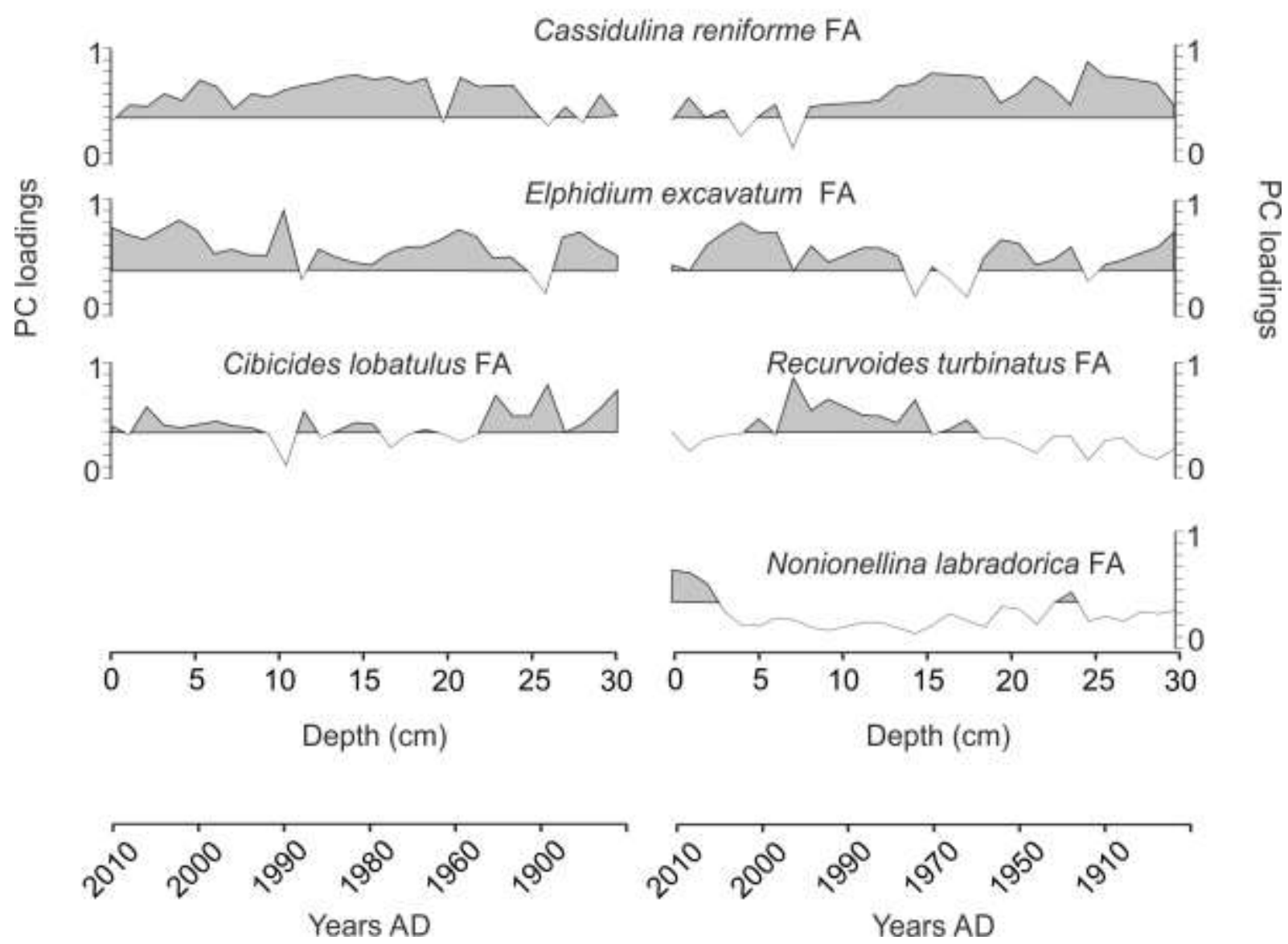

Figure 7. PC loading values for foraminiferal assemblages in the studied cores. Statistically significant PC loadings $(>0.4)$ are marked in grey.

\section{Tables captions}

Table 1. Foraminifera indicator groups distinguished after Majewski et al. (2009).

Table 2. PC scores and percentage of total variance explained by 3-factor principal component (PC) analysis performed on the NORTH (A) and SOUTH (B) datasets. Species significant for each assemblage are marked in bold. 


\section{Supporting information}

Table S1. List of species and number of individuals found in the NORTH core.

Table S2. List of species and number of individuals found in the SOUTH core. 